\title{
EFFECT OF UNDERNUTRITION IN EARLY LIFE ON PHYSICAL AND MENTAL DEVELOPMENT
}

\author{
BY \\ VERA CABAK and R. NAJDANVIC \\ From the Paediatric Clinic, Sarajevo, Yugoslavia
}

(RECEIVED FOR PUBLICATION AUGUST 14, 1964)

It was pointed out by Trowell, Davis, and Dean (1954) that, 'Nothing is known about the completeness of recovery from severe kwashiorkor', and this is to a large extent still true. An increase in the body weight is admittedly a sign of recovery, and indeed a very important criterion of it, but unless the final weight and height attained are also known it is impossible to say whether it has been complete. The experiments on animals give some information about this problem. McCance and Widdowson (1962) showed that the body weights of rats undernourished during suckling never reached those of their controls in spite of subsequent unlimited food. Undernutrition for the first six months of life can also affect the final stature of cockerels (Pratt and McCance, 1961), but this has not been found to be true of all species and for these differences references should be made to Aron (1911), Moulton, Trowbridge, and Haigh (1921), Jackson (1925), Clarke and Smith (1938), Crichton, Aitken, and Boyne (1959), and McCance (1962). The extent of the undernutrition and the age at which it affects the animal are also certainly important (Widdowson and McCance, 1963).

Even less is known about the mental than about the physical development of children after a period of undernutrition (Stoch and Smythe, 1963; Graham, 1964). Attention has been drawn to defects in their ability to learn a language (Waterlow, Cravioto, and Stephen, 1960), which is one of the most important ways of estimating the intelligence of a child (Stevanović, 1937). Jersild (1955) has stated that, 'A positive relationship is usually found between language ability and mental ability.' Many authors, moreover (Porter, 1895a, b; Boas, 1940; Tanner, 1955), have found that children who are physically advanced for their age score higher in mental tests than those who are less mature, but of the same chronological age. Lat, Widdowson, and McCance (1960) showed this to be true also of rats.

\section{Material and Methods}

Children were selected from the records who had been admitted for malnutrition (marasmus) to the Hospital for sick children in Sarajevo between 1951 and 1957. Though slight oedema was present in a few, there were no other signs of kwashiorkor. Their ages at the time were between 4 and 24 months. At the time of admission they had all been $27 \%$ or more below the correct weight for their age, according to the tables of Lust, Pfaundler, and Husler (1953). Children suffering from chronic diseases such as tuberculosis or diseases of the central nervous system were excluded from the investigation and, for financial reasons, only children from the town of Sarajevo were invited to attend. This restricted the numbers and, for various reasons, some did not come, sothat finally only 36 children were available. The history of the health and development of these children after discharge was taken, the body weight and height were measured, the intelligence was tested by Binet-Simon scale as adapted by Stevanović (1937), and finally their grade at school was recorded. At the time of the followup assessment their ages were between 7 and 14 years. The parents of these children were mainly unskilled and skilled workers, but about one-third was drawn from the professions or were army officers.

\section{Results}

Fig. 1 shows the deficits in the expected weight for age at the time of admission plotted against the age. Most of the cases were less than 12 months old and all the most serious were below this age.

The body weights of these children at the time of interview are shown in Fig. 2 in comparison with the weights of the healthy schoolchildren of Sarajevo (Jelisavčić-Mihal, 1961). More of the children were below the standard curve at 7 or 8 years of age than later, but the mean values and the standards were not significantly different at any age by the ' $t$ ' test.

Fig. 3 shows the heights of the 36 children, also in comparison with local standards. The results are similar to those for weights. 


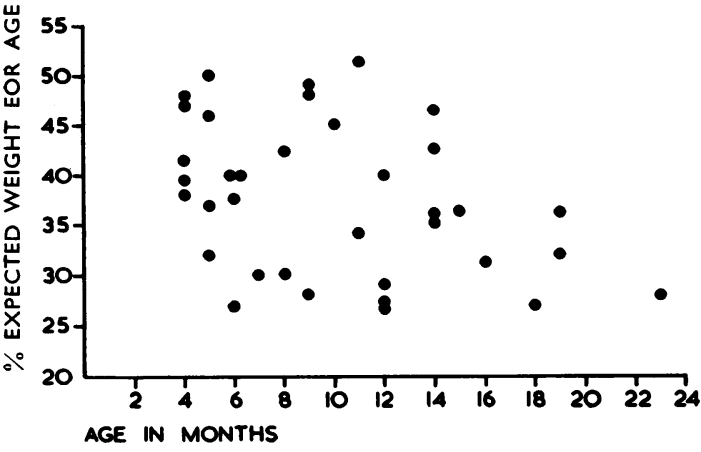

FIG. 1.-Deficit in body weight of the undernourished children, expressed as a percentage of the weight to be expected at that age, plotted against their age on admission.

The results of the intelligence tests are shown in Fig. 4. Only 18 were within the normal IQ limits (91-110), 12 were 'stupid', with IQs between 71 and 90 , and the remaining 6 children had IQs of 70 or below. None showed an IQ greater than 110 . In other words, half the children were below the limit of normal intelligence, and this difference between normal and subnormal intelligence was highly significant by the Kolmogorov Smirnov test ( $\mathrm{p}=$ $0 \cdot 01$ ).

There are no local standards for the dispersion of the intelligence quotient, so the present results have been compared with those for Serbian children (Stevanović, 1957). Of the Serbian children, $21 \%$ were below normal intelligence as against $50 \%$ of the previously undernourished children, and $32 \%$ of the Serbian children were above the range of the under-

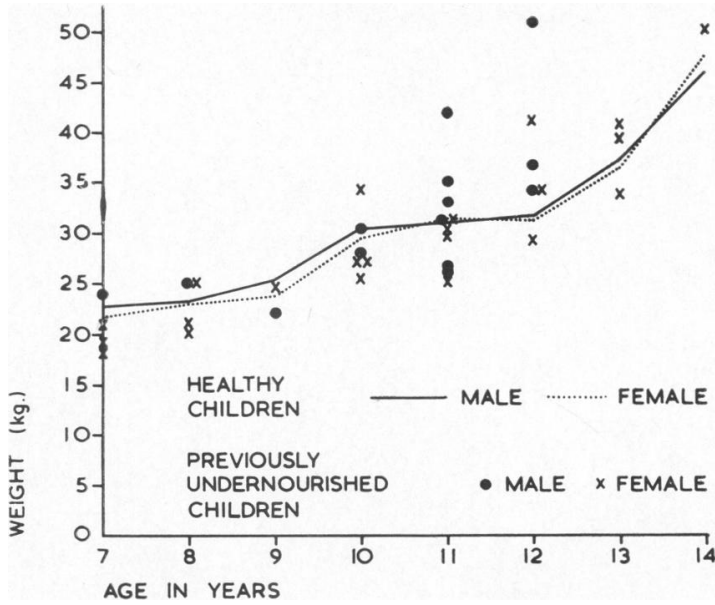

FIG. 2.-The body weights of the 36 previously undernourished children when they attended for interview compared with the weights of healthy schoolchildren in Sarajevo.

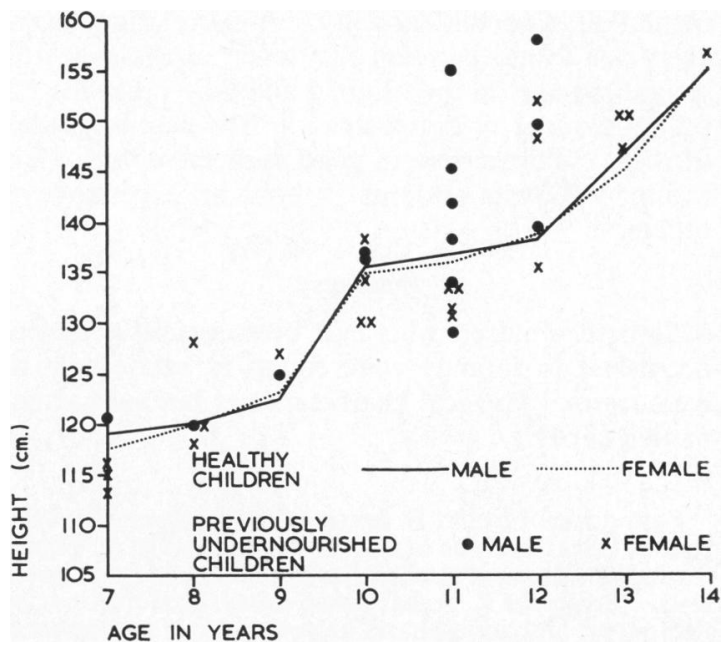

FIG. 3.-The heights of the 36 previously undernourished schoolchildren when they attended for interview compared with the heights of healthy schoolchildren in Sarajevo.

nourished children. The mean IQ of the undernourished series was 88 , in contrast to 101 for children from Mostar, 80 miles from Sarajevo, and 109 for children from Beograd. It is well known that socio-economic factors influence the IQ but even if all the undernourished children had come from families of 'non-qualified' workers their IQ was below the mean value of 93 for this group.

No correlation was found using the Spearman test (Siegel, 1956) between the age of the children when they were ill and undernourished and their subsequent

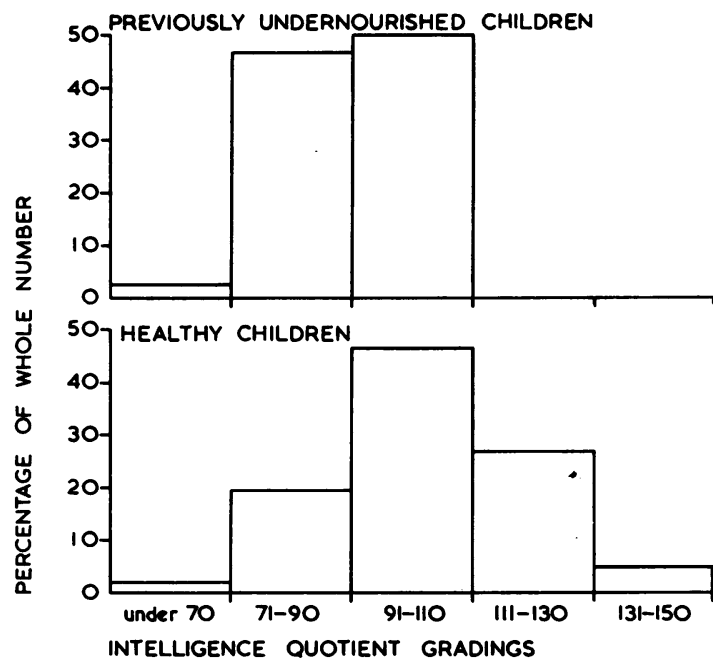

FIG. 4.-The distribution of quotients of intelligence shown by the 36 undernourished children compared with the standards established for Serbian children. 
mental development and IQ. A correlation, however, was found between the deficit in the expected weight for age on the original admission and the IQ on subsequent re-examination. The school grades of these children were in good agreement with their rating by IQ tests, and this confirms the experience of others.

\section{Summary}

Serbian children who had been seriously undernourished in infancy were found at school-age to have normal physical characteristics but subnormal mental capacity.

I am grateful to Dr. E. Serstnev for his assistance with the statistical analysis of the results and to Dr. L. Skoric for help in the appraisal of the results of the intelligence tests. Professor R. A. McCance encouraged me to write this paper, and advised and helped me over its presentation. I would like to thank him for all he has done.

\section{REFERENCES}

Aron, H. (1911). Nutrition and growth. Philipp. J. Sci. B., 6, 1. Boas, F. (1940). Race, Language and Culture. MacMillan, New York.

Clarke, M. F., and Smith, A. H. (1938). Recovery following suppression of growth in the rat. J. Nutr., 15, 245.

Crichton, J. A., Aitken, J. N., and Boyne, A. W. (1959). The effect of plane of nutrition during rearing on growth, production, reproduction and health of dairy cattle: 1. Growth to 24 months. Anim. Prod., 1, 145.

Graham, G. (1964). Diet and Bodily Constitution. Ciba Foundation Study Group No. 17, p. 11. J. \& A. Churchill, London.
Jackson, C. M. (1925). The Effects of Inanition and Malnutrition Upon Growth and Structure. J. \& A. Churchill, London.

Jelisavčič-Mihal, M. (1961). Prilog antropometrijkom ispitivanju skolske omladine. Biltin Rep. Z. za Zdrav. zaštitu br., 1-2, 78. Jersild, T. A. (1955). Child Psychology, 4th ed., p. 417 . Staples Press, London.

Lat, J., Widdowson, E. M., and McCance, R. A. (1960). Some effects of accelerating growth: III. Behaviour and nervous activity. Proc. roy. Soc. $B, 153,347$.

Lust, F., Pfaundler, M. von, and Husler, J. (1953). Krankheiten des Kindesalters. Urban \& Schwarzenberg, Munich.

McCance, R. A. (1962). Food, growth, and time. Lancet, 2, 621, 671.

- and Widdowson, E. M. (1962). Nutrition and growth. Proc. roy. Soc. $B, 156,326$.

Moulton, C. R., Trowbridge, P. F., and Haigh, L. D. (1921). Studies in animal nutrition: 1 . Changes in form and weight on different planes of nutrition. Res. Bull. Mo. agric. Exp. Sta., 43, 73.

Porter, W. T. (1895a). The physical basis of precocity and dullness. Trans. Acad. Sci. St Louis, 6, 161.

- (1895b). The relation between the growth of children and their deviation from the physical type of their sex and age. ibid., 6 , 233.

Pratt, C. W. M., and McCance, R. A. (1961). Severe undernutrition in growing and adult animals: 6 . Changes in the long bones during the rehabilitation of cockerels. Brit. J. Nutr., 15, 121.

- Siegel, S. (1956). Nonparametric Statistics: for the Behavioral Sciences. McGraw Hill, New York.

Stevanović, B. (1937). Merenje Inteligencije. Ed. Drag. Gregorič, Belgrade.

- (1957). Pedagoška psihologija. Ed. Naučna Knjiga, Belgrade.

Stoch, M. B., and Smythe, P. M. (1963). Does undernutrition during infancy inhibit brain growth and subsequent intellectual development? Arch. Dis. Childh., 38, 546.

Tanner, J. M. (1955). Growth at Adolescence. Blackwell, Oxford. Trowell, H. C., Davis, J. N. P., and Dean, R. F. A. (1954) Kwashiorkor, p. 225. Edward Arnold, London.

Waterlow, J. C., Cravioto, J., and Stephen, J. M. L. (1960). Protein malnutrition in man. Advanc. Protein Chem., 15, 131.

Widdowson, E. M., and McCance, R. A. (1963). The effect of finite periods of undernutrition at different ages on the composition and subsequent development of the rat. Proc. roy. Soc. B, 158, 329. 